\title{
Land Reform in NE Brazil: a stochastic frontier production efficiency evaluation ${ }^{1}$
}

\author{
Marcelo Marques de Magalhães ${ }^{2}$ \\ Hildo Meirelles de Souza Filho ${ }^{3}$ \\ Miguel Rocha de Sousa ${ }^{4}$ \\ José Maria F. J. da Silveira \\ Antônio Márcio Buainain ${ }^{6}$
}

\begin{abstract}
The aim of this paper is to address the sources of technical and allocative inefficiency from a cross section sample of 308 beneficiaries of a market assisted land reform program, called "Cédula da Terra" from five states in Northeastern region of Brazil. In spite of some differences on governance of the "Cédula da Terra" in comparison with traditional expropriation land reform program, studies carried by Buainain et al. (2002) have shown small differences between then, regarding their social and economic characteristics. We believe that our results could be useful to identify the main problems of Brazilian land reform settlements. We estimated a potential production frontier following the methodology of Battese and Coelli (1995), Coelli et al. (1998) and applied econometric techniques to explain inefficiency. The results indicate the existence of technical and allocative inefficiency, which is identified mostly in situations where the presence of production for consumption is high. This is a result that shows how immature the agriculture activity is in most of Cédula da Terra Program settlements and
\end{abstract}

1 The authors wish to thank suggestions from Valentina Buainain and Marcelo Melo at Unicamp and Aurora Galego and Joaquim Ramalho at Universidade de Évora. This manuscript contains no copyright infringements and the authors all agreed to give SOBER exclusive copyright and publishing rights.

2 Professor da Universidade Estadual de São Paulo (UNESP), Tupã. E-mail: marcelo@tupa.unesp.br

3 Grupo de Estudos e Pesquisas Agroindustriais, DEPE/UFSCar. E-mail: hildo@dep.ufscar.br

4 Universidade de Évora, Departamento de Economia, Colégio do Espírito Santo. E-mail:mrsousa@uevora.pt

5 Professor Doutor Unicamp, Instituto de Economia. E-mail: jmsilv@eco.unicamp.br

6 Professor Doutor Unicamp, Instituto de Economia. E-mail: buainain@eco.unicamp.br 
the difficulty to overcome the limitations imposed by the initial condition of formation of agrarian reform, primarily in Northeastern region of Brazil.

Key-words: Land Reform, Human Capital, Technical Assistance, Rural Credit, Stochastic Frontier.

Resumo: O objetivo desse artigo é caracterizar as fontes da ineficiência técnica e alocativa em um conjunto de 308 beneficiários de um programa de reforma agrária de mercado, chamado "Cédula da Terra", distribuídos em cinco estados do Nordeste brasileiro. Estudos conduzidos por Buainain et al. (2002) mostraram existem poucas diferenças entre as características de beneficiários deste programa e dos programas tradicionais de reforma agrária por expropriação e que portanto, os resultados obtidos por este trabalho permitem visualizar as dificuldades enfrentadas pelos assentamentos no Brasil. Para medir eficiência, estimou-se uma função de produção potencial segundo a metodologia de Battese e Coelli (1995) e a partir disto, procurou-se explicar as razões da ineficiência (relativa) encontrada. Os resultados apontam para a existência de ineficiência técnica e alocativa que é identificada principalmente nas situações em que a presença de produção para consumo é elevada. Tratase de um resultado que revela a pouca maturidade da maioria dos lotes dos assentados do PCT e a dificuldade de superar as limitações impostas pela condição inicial de formação dos assentamentos de reforma agrária, principalmente na região nordeste do Brasil.

Palavras-chave: Reforma Agrária, Capital Humano, Assistência Técnica, Crédito Rural, Fronteira Estocástica.

\section{Classificação JEL: Q15.}

\section{Introduction}

Recent reinforcement of agrarian reform initiatives in Brazil since mid 90s have re-lighted the debate regarding both the validity of agrarian reform as an instrument of social inclusion and the sustainability of reformed settlements. Assessments of settlements have yielded conflicting and non-conclusive results. Just to quote some of the more recent studies, Leite et al. (2004) produce a rather positive picture of settlements whereas Sparovek (2003) analysis of data from almost 5000 settlements spread all over the country highlights severe deficiencies both on infrastructure and performance.

Land reform has been questioned in terms of social and economic results, in particular the ability to create and consolidate a dynamic family farm sector within reformed perimeters. One can always argue, as we ourselves have done, that agrarian reform settlements are long-term enterprises and should not be assessed on short-term performance. However, the question is whether short-term performance justifies optimism in terms of long-term performance (BRITANNICA, 1993; BRITANNICA, 2001; KAWAGOE, 1999). 
There are doubts regarding the sustainability of agrarian reform projects. Analyzing the immediate effects of traditional and market assisted projects in five Northeastern region states. Buainain et al. (2002) found poor results: most families were still trapped in traditional subsistence production, very low productivity and low management capacity. However, is important to pay attention to the fact that results also showed high variance of land reform beneficiaries' economic performance. ${ }^{7}$ Under severe resource constraints, ability to organize production and make better use of available resources is crucial to lead beneficiaries toward an out of poverty trap.

While strong ideological interference and data deficiency have truncated the debate, it is rather desirable we should grasp every opportunity to enlighten controversial issues and fuel the debate with solid and objective analyses of relevant aspects of agrarian reform.

The Cédula da Terra Program was initiated in 1997, first as a pilot, in the state of Ceará, in the Northeastern region of Brazil, and later extended to cover also the states of Bahia, Maranhão, Minas Gerais and Pernambuco. Between 1997 and 2002 the PCT benefited 15,255 families, with a total program cost of approximately R \$ 100 million. In the year 2003, the PCT evolved into the Crédito Fundiário Program, which has the same basic structure of its predecessor and has settled, up to September 2008, 62,990 families (CGPMA, 2008).

The PCT use a demand-driven structure, where groups of landless and minifundia farmers apply to the program through formally constituted associations, either created for that purpose or previously existing. Apart from some general selection criteria including, for instance, a maximum family income and experience working in agricultural activities, the selection process follows a "first-come first-serve" basis, in each state. The total amount of funding available per association is fixed, including the loan for land purchase and the grant for investments, thus creating an incentive for associations to negotiate for lower land prices, what leaves more available funding for investments.

In other words, land is not distributed but purchased through regular land market operation by landless/small producers associations. The Project provides land loans to be paid under special favored conditions and defines a set of rules and incentives to promote better efficiency use of resources. Access to loans is conditioned to compliance with certain general features and abeyance to established rules. In addition, state agencies responsible for implementing the program monitor land negotiations between associations and land owners ${ }^{8}$ (see ROMANO et al., 2008).

7 This variance is partially due to factors such as drought and the variability of weather conditions and the immaturity of the projects.

8 For more details about the program operational structure see Buainain et al. (2003). For a comparison between alternative governance structures in Brazilian Land Reform, see Silveira et al. (2008). 
The innovations introduced about land reform in Brazil by the PCT are not confined only to the use of credit for land purchase by a community of landless, but include also new concepts in terms of governance structure, putting more emphasis on active participation of beneficiaries from the inception of the project, including land negotiation, design of the agricultural production plan and formal responsibility for loan re-payment. This approach adds an important alternative to the available mechanisms for land reform and poverty reduction in Brazil.

The idea of land reform settlements is based on the access of the rural poor and landless people to some specific services to promote agriculture production. According to the literature, the analytical relationship between higher technical assistance and higher output is a direct one, because it enables them to increase the potential production; that is they use new techniques, and/or in a better way older techniques, thus using in a more efficient manner production, which finally shortens the gap between actual and potential production. Technical assistance might also have a decisive role in the choice of products and/or in the access to markets at better prices, thus yielding a direct impact on the value of production (see EVENSON, 1988). The same reasoning could be applied credit, in the sense that it provides better access to use resources, particularly investment expenditures and better ways of accession to commercial flows and prices. Contracting a debt generate incentives to looking for monetary income (BUAINAIN et al., 1999a).

Social production in the settlements is related to the use of common resources - pertaining to farmers' Associations - especially the resources devoted to it by PCT which enabled the creation of better use opportunities in society with higher availability of fixed and variable inputs, technical assistance, better land tillage, pastures, and better genetic bred animals, better access to markets and better prices (BUANAIN et al., 1999b; BUAINAIN et al., 2002; BUAINAIN et al., 2003). This hypothesis would be verifiable even in situations when the output wasn't totally collective, namely, the initial start up costs of exploring the fields, irrigation, and so on, were realized in an associative way, but afterwards the field was divided among farmers with the objective of individual production.

The aim of this paper is to characterize the sources of technical and allocative inefficiency in a sample of five Northeastern Brazilian states subject to a land reform pilot project - the Cédula da Terra Program (PCT). We evaluated the PCT pilot project, a land reform project whose conception, mechanisms and operational structure is, theoretically, different from traditional agrarian reform based on expropriation. However, this assessment sheds some light on the situation faced by land reform settlements in Northeast Brazil, pioneering the main factors that explain their relative efficiency. The paper is also important to generate a reference for future studies in this field. 


\section{Potential Production Frontier: Considerations about Technical Inefficiency}

The technical efficiency might be defined as the maximum output for a producer that can be attained given some level of inputs, and some set of available technologies. Allocative efficiency refers itself to the adjustment of inputs and outputs as a consequence of relative price changes. It shows the ability of the producer to combine inputs and outputs in optimal proportions given prevailing prices (SADOULET e DE JANVRY, 1995).

Economic efficiency is a situation in which technical and allocative efficiency is combined. The analysis presented in the section of technical and allocative efficiency evaluates these efficiencies starting from the value of output, which was generated by the use of productive inputs (namely land, labor and working capital) and conditioned by the use of socio-economic and environmental (a proxy) variables - which we further explain below. Thus, technical and allocative efficiency is evaluated simultaneously, because the value of output depends not only of quantities produced but also on the set of prevailing prices and farmers have different factor endowments (see SADOULET e DE JANVRY, 1995 for a brief review on efficiency with a focus on rural development; for a more abstract and theoretical point of view, see FARE, GROSSKOPF e LOVELL, 1994).

The traditional efficiency analysis has been performed using two approaches: parametric methods - least-squares econometric production models and stochastic frontier analysis (SFA) - and non-parametric methods - total factor productivity indices (TFP) and data envelopment analysis (DEA) Least-squares econometric models and TFP assume all firms technically efficient and have been most often applied to aggregate time-series data, providing measures of technical change and total factor productivity. On the other hand, SFA and DEA do not assume that all firms are technically efficient, providing relative measures of efficiency among firms of a cross-section dataset sample - both methods can be used to measure technical and efficiency changes if panel data is available. DEA uses linear programming methods to construct a non-parametric frontier surface over production data, while SFA uses econometric estimation of parametric functions to construct the frontier surface. The deterministic approach of DEA considers all deviations of the frontier as inefficiency, while it is possible to discriminate between differences in inefficiency and random errors by stochastic frontier analysis.

The differences among the methods and the characteristics of our farms' dataset led us to choose stochastic frontier analysis. This method provides relative comparison of productivity efficiency within the sample farms, in a point in time, using a cross-section dataset. In addition, it gives both efficiency differences and random errors without the assumption of full technical efficiency among firms. ${ }^{9}$

9 For an extensive view of productivity measurement methods see Coelli, Rao e Battese (1998). 


\subsection{Econometric Specification of the model}

Stochastic frontier production models might be specified in the following way:

$$
Y_{i}=f\left(x_{i} ; \beta\right) \cdot \exp \left(V_{i}-U_{i}\right) \quad \text { with } i=1, \ldots, N .
$$

where $Y_{i}$ stands for production of the $i^{\text {th }}$ firm, $x_{i}$ are inputs and $\beta$ are the parameters of production function. The random component $V_{i}$ is a white noise shock, which shifts the potential production frontier. The other random part $U_{i}$ represents technical inefficiency and we try to explain it within the model. Its distribution is non-negative, unilateral and might usually be half-normal, exponential or truncated-normal.

The distribution of $V_{i}$ is bilateral and reflects random effects, measurement errors and omitted variables errors. One should notice that the value of the stochastic frontier's production function in the model is given by: $Y_{i}^{*}=f\left(x_{i} ; \beta\right) \cdot \exp \left(V_{i}\right)$.

The objective of this model is to explain technical efficiency $\left(T E_{i}\right)$ as a random component which is determined by the relation between effective and potential production: $T E_{i}=\frac{Y_{i}}{Y_{i}^{*}}$, and $T E_{i}=\frac{f\left(x_{i} ; \beta\right) \cdot \exp \left(v_{i}-U_{i}\right)}{f\left(x_{i} ; \beta\right) \cdot \exp \left(V_{i}\right)}=\exp \left(-U_{i}\right)$.

Efficiency estimation has been proceeding in one-single-step or in twosteps. Sharif and Dar (1996) and Wang et al. (1996) used two-steps procedure on efficiency measurement. In the first step, the estimation of a production function frontier calculates only the parameters of the production function, ignoring the effect of firm characteristics on inefficiency. The inefficiencies are estimated in the second step, by the regression of technical inefficiency components on firm characteristics.

Coelli (1996) considers the assumptions regarding the independence of inefficiency effects in the two estimation stages, which produces two sources of bias described by Wang and Schmidt (2001). The first source is related to the regression parameters bias as a result of the correlation of the inputs and firm characteristics (inefficiency explanatory variables). The second source is revealed when the effect of firm characteristics on efficiency are ignored in the first step, leading to under-dispersed inefficiency measures in the second step. The effect of firm characteristics on efficiency is biased toward zero.

The single-step method of Battese and Coelli (1995) provides the estimation of the firm inefficiency measures according to the firm characteristics and explaining efficiency differentials among firms at same time. Battese and Coelli (1995) extended the stochastic production frontier model, considering that the inefficiency effects are given by a linear function of explanatory variables (firm characteristics). 
The technical efficiency effects model $\left(T E_{i}\right)$ of Battese and Coelli (1995) might be written as:

$$
Y_{i t}=x_{i t} \beta+\left(V_{i t}-U_{i t}\right)
$$

where $Y_{i t}$ is the $\log$ output of the $i^{\text {th }}$ agricultural firm on period $t ; x_{i t}$ is a (1 $\mathrm{x} k$ ) transformation vector of the quantities of the $i^{\text {th }}$ firm's inputs on period $t$; $\beta=\left(\beta_{0}, \beta_{1}, \ldots, \beta_{K-1}\right)$ is a $(k \times 1)$ vector of unknown parameters to be estimated and $V_{i t}$ are considered to be i.i.d. and $V_{i t} \sim N\left(0, \sigma_{V}^{2}\right)$; and $U_{i t} \sim N^{+}\left(m_{i t}, \sigma_{U}^{2}\right)$, where $m_{i t}=z_{i t} \delta$ ,$z_{i t}$ is a vector of variables of the firm characteristics that might influence its productive inefficiency $(\delta)$.

The likelihood function is explained as a function of the model's parameters variance: $\sigma^{2}=\sigma_{U}^{2}+\sigma_{V}^{2}$, in which we define as $\gamma=\sigma_{U}^{2} /\left(\sigma_{U}^{2}+\sigma_{V}^{2}\right)$. The model yields a better fit whenever $\gamma$ goes to 1, because a greater part of the deviation from the frontier is explained by the technical inefficiency components.

A common criticism about stochastic frontier analysis is that there is not a prior justification for assuming a particular distribution form for technical inefficiency effects $\left(U_{i t}\right)$. Distribution problems are observed under zeromode distributions like half-normal form. Zero-mode distribution implies a bias toward low inefficiency levels, as most part of $U_{i t}$ tends to be nearby zero (COELLI et al., 1998). Stevenson (1980) specified a model assuming a truncatednormal distributional form, which is a generalization of the half-normal distribution. Truncated-normal distribution alleviates the problems of zeromode distributions, because it allows for a wider range of distributional forms, including non-zero mode forms.

Stochastic frontiers are usually estimated on Cobb-Douglas functional form, but alternative functional forms, like translog, have also been used. Cobb-Douglas is easy to estimate, it is simple, however it brings with it restrictive properties. It has constant input elasticities, constant returns to scale, and the elasticities of substitution are equal to one. Translog form has been an interesting alternative to Cobb-Douglas because it imposes no restrictions upon returns to scale or substitution possibilities, but it has the drawback of being susceptible to multicollinearity and degree of freedom problems (COELLI et al., 1998).

\section{Empirical Application}

The present study of productive efficiency of beneficiaries of Cédula da Terra Program used a dataset survey of the study of Buainain et al. (2003). This study uses data from a survey of 308 households of PCT from 103 settlements. The survey covered the five states where the Program was being implemented in 2000: Bahia, Ceará, Maranhão, Minas Gerais and Pernambuco. 
Stratification was done at the level of homogeneous region and municipality in the 5 states, to guarantee a spatial coverage of the whole PCT. After identifying the 103 PCT settlements distributed in the 5 states according to the relative importance of the Project in each of them, three out of the five treatment sample households were randomly selected and interviewed. This procedure has made the sample representative of the PCT. Any comments on the parameters estimated by the econometric analysis are pertinent to the Project as a whole, not for a specific region or state. Details of the sample procedures can be found in Buainain et al. (2003).

The whole dataset has much more than productive data. It has data regarding demographic variables, living standards, household assets and productive assets. The productive data is detailed in subsets containing variables about land use, labor allocation, inputs and costs, level of production technology, cattle, and cropping.

The production function for the present paper was set using total value of output, cultivated land, labor days, and costs for inputs. Inefficiency effects variables stand for years of schooling, access to credit and technical assistance, production for consumption, collective production, and dummy variables for northeastern Brazilian states. The last dummy variables represent different environmental and institutional operation conditions.

The sample planning of Buainain et al. (2003) research was designed to represent the whole set of PCT's settlement projects deployed from 1997 to 1998. That population corresponds to 209 settlements and 6253 households. The final sample had 119 projects with 308 households. The survey took place in 2003 , thus the lifetime of the settlements was around 5 years.

Starting from the original specification of Battese and Coelli (1995) and then applying natural logarithm (base $e$ ), the stochastic frontier production function to be estimated is

$$
\ln \left(Y_{i}\right)=\beta_{0}+\beta_{1} \ln \left(\text { Land }_{i}\right)+\beta_{2} \ln \left(\text { Labor }_{i}\right)+\beta_{3} \ln \left(\text { Inputs }_{i}\right)+V_{i}-U_{i}
$$

where $i$ refers to the $i^{\text {th }}$ farm data vector of production factors;

$Y$ is the total value of output in Brazilian Reais (R\$). It refers to the value of agricultural production, includes cattle and crop production, derivatives and other products, individual and collective production, also monetary and nonmonetary production. The value of production sales was based on the farmer's declared prices. The value of non-monetary production (family consumption), was obtained by the imputation of prices in the following order: selling prices declared by the beneficiary, when part of the production is sold; average selling prices declared by other beneficiaries on the same project; average selling prices declared by other beneficiaries of the same municipality; the same for micro-region, meso-region, state, and the set of the five states; 
Land is the total area of cultivated land with permanent and temporary crops, pastures and others in hectares (ha);

Labor is the number of working days inside and outside the parcel, but within the project settlement. It includes resident dwellers, third parties, and members of the family who are not residents of the household;

Inputs are the total spending with variable inputs such as feed, silage, palm, grain, salt, vaccines and medicines, seeds, fertilizers and correctives, pesticides, packages, fuels and lubricants, and water for irrigation. All values are in current Brazilian Reais (R\$);

$\beta_{1}$ to $\beta_{3}$ are the unknown parameters of the production function to be estimated; $V_{i}$ are the random errors as defined in the section above; and $U_{i}$ are variables associated with technical inefficiency of production.

The technical inefficiency effects are assumed to be

$$
\begin{aligned}
U_{i}=\delta_{0} & +\delta_{1}\left(M G_{i}\right)+\delta_{2}\left(M A_{i}\right)+\delta_{3}\left(C E_{i}\right)+\delta_{4}\left(B A_{i}\right) \\
& +\delta_{5}\left(\text { Schooling }_{i}\right)+\delta_{6}\left(\text { TechAssist }_{i}\right)+\delta_{7}\left(\text { Credit }_{i}\right) \\
& +\delta_{8}\left(\text { PCollective }_{i}\right)+\delta_{9}\left(\text { PConsumption }_{i}\right)
\end{aligned}
$$

where $i$ refers to the $i^{\text {th }}$ farm data vector of inefficiency explanatory variables; $M G$ is a dummy variable that takes value 1 for Minas Gerais state beneficiaries; $M A$ is a dummy variable that takes value 1 for Maranhão state beneficiaries; $C E$ is a dummy variable that takes value 1 for Ceará state beneficiaries; $B A$ is a dummy variable that takes value 1 for Bahia state beneficiaries; ${ }^{10}$ Schooling is the years of formal schooling of beneficiaries (head of household); TechAssist is the technical assistance dummy variable that takes value 1 for the presence of monthly technical assistance between August/2002 and July/2003; Credit is the credit dummy which takes value 1 for beneficiaries who received credit at least once since the deployment of the settlement until July/2003, excluding regular funding of PCT;

PCollective is the ratio of collective production value and total value of output $(Y)$. The collective production comes from common shared land or common shared small agro-industry, like small plots for production of flour and/or starch of cassava;

PConsumption is the ratio of the value of production consumed by the beneficiary family and the total value of output value $(Y)$;

$\delta_{0}$ to $\delta_{9}$ are the unknown scalar parameters or inefficiency coefficients to be estimated.

10 The State of Pernambuco (PE) was omitted from the inefficiency explanatory variables to avoid multicollinearity. 


\section{Descriptive Analysis of the Data}

The model above is a linearized version of the Cobb-Douglas production function, in which the production output is a function of land used for crops and cattle, labor, and costs of inputs. The stochastic frontier model assumes a truncated-normal distribution for the technical inefficiency effects, which corresponds to Model 2 of Frontier 4.1, software used to estimate the maximumlikelihood parameters of the model (COELLI, 1996). The inefficiency frontier model accounts for effects related to the differences of five northeastern Brazilian states, years of schooling, access to technical assistance, access to credit, collective production, and family consumption. The data used is a cross-section sample, which can be considered a particular case of a panel data model when $\mathrm{T}=1$. Annex I presents a more accurate definition of the variables included in the model.

We proceeded to a brief descriptive analysis of the data to use in the model. Descriptive tables of the more relevant variables of the model and its graphics with an adjusted normal distribution are presented below.

Table 1. Descriptive statistics of variables used in the SFA -

Sample of beneficiaries of Cédula da Terra Program, 2003 ( $n=308)$.

\begin{tabular}{|c|c|c|c|c|}
\hline Group & Variable & Average & $\begin{array}{c}\text { Standard } \\
\text { Error }\end{array}$ & $\begin{array}{l}\text { Dispersion } \\
\text { Coefficients }\end{array}$ \\
\hline \multirow{4}{*}{$\begin{array}{l}\text { Production } \\
\text { function } \\
\text { variables }\end{array}$} & Output (R\$) & 3770.5280 & 3281.3546 & $87 \%$ \\
\hline & Land (ha) & 7.7868 & 10.2161 & $131 \%$ \\
\hline & Labor (days) & 557.0617 & 367.3379 & $66 \%$ \\
\hline & Inputs $(\mathrm{R} \$)$ & 317.2607 & 676.7240 & $213 \%$ \\
\hline \multirow{11}{*}{$\begin{array}{l}\text { Technical } \\
\text { Inefficiency } \\
\text { Explanatory } \\
\text { Variables }\end{array}$} & MG (dummy) & 0.1169 & 0.3218 & $215 \%$ \\
\hline & MA (dummy) & 0.1753 & 0.3809 & $217 \%$ \\
\hline & CE (dummy) & 0.3084 & 0.4626 & $150 \%$ \\
\hline & BA (dummy) & 0.2208 & 0.4154 & $188 \%$ \\
\hline & Schooling (years) & 1.8896 & 2.7373 & $145 \%$ \\
\hline & Technical assistance (dummy) & 0.2208 & 0.4154 & $188 \%$ \\
\hline & Credit (dummy) & 0.5000 & 0.5008 & $100 \%$ \\
\hline & Collective output (R\$) & 550.4840 & 1274.3288 & $231 \%$ \\
\hline & Proportion of collective output & 0.1350 & 0.2176 & $161 \%$ \\
\hline & Output for consumption $(\mathrm{R} \$)$ & 1730.9350 & 1947.5737 & $113 \%$ \\
\hline & Proportion of output for consumption & 0.5160 & 0.2881 & $56 \%$ \\
\hline
\end{tabular}

Source: Research data (2003). 
As shown in Table 1, the value of agricultural production has a high dispersion (87\%) and the average plot of land is small (7.8 ha, with a dispersion of $131 \%)$. Inputs have a very high variability $(213 \%)$ and labor (in days) is the variable with a small dispersion (66\%). Thus, we might conclude that in the production function labor is the most stable production factor. This is a quite accurate picture of small poor peasants' production structure and organization in northeastern region of Brazil: small plots whose size may vary according to geographical conditions (larger areas in the Sertão and smaller farms in the Humid Coast Zona da Mata or Agreste), low application of modern technology and intensive use of family labor.

Years of schooling have a very low absolute value (1.89 years) with a considerably high dispersion (145\%). The distribution of years of schooling reveals itself biased towards values below its means of 1.89 years. One should notice that education has been a major income determinant for rural households, as several international studies show - thus, this justifies the inclusion of this variable in the model - see for instance, Becker (1993), Kageyama and Hoffman (2000) for Brazil. This study finds that schooling above the first degree is a determinant factor of rural income. The reality of poor rural NE region areas is accompanied by very low levels of education, making difficult to infer the effect of the variable.

One should stress that the value of collective production has the highest coefficient of dispersion (231\%), as long as self-consumption has the highest mean value (R\$ 1730.93), with a smaller dispersion (113\%). The distribution of the value of social production is skewed, highlighting the low level of social capital of rural poor in the region (see SILVEIRA et al., 2008). It is theoretically important to remember that the governance of PCT is based on the advantages of collective (or associative) production (see BUAINAIN et al., 1999b).

The value of self-consumption presents again a pattern of bias below the average. 
Figure 1. Distribution of production function's variables: (a) output (R\$); (b) cultivated area (ha); (c) labor days; (d) costs (R\$). Sample of beneficiaries of PCT, $2003(n=308)$.
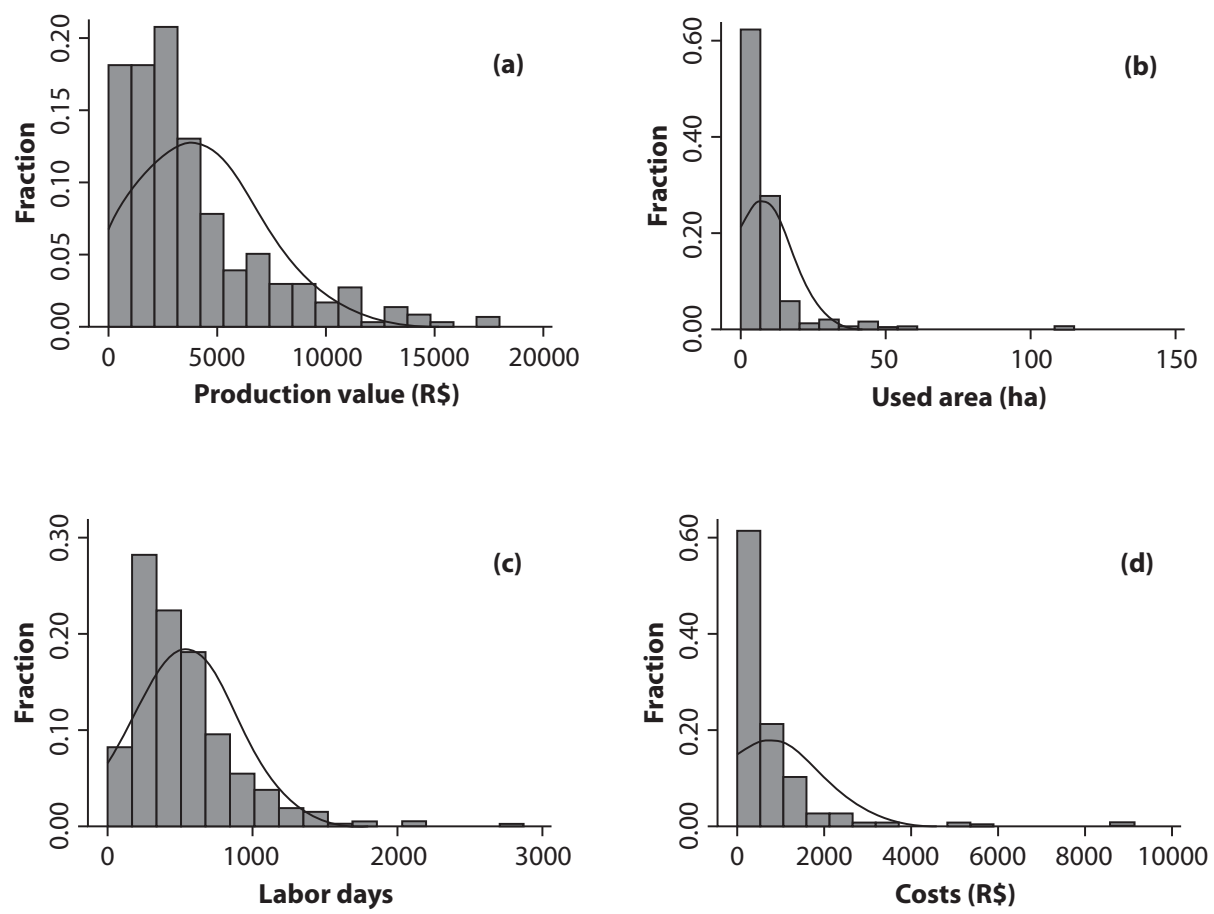

Source: Research data (2003).

The observation of Figure 1 visually confirms that the value of production and cultivated area have distributions which might be approached by the truncated normal distribution. The distribution of labor (days) presents data more concentrated around the mean. Nevertheless, the cost of inputs presents a distribution very concentrated around the first frequency class and with a very high dispersion. In spite of the characteristics of some variables described above, they sustained a good fit of the production function model - as we can observe next on Table 2 . 
Figure 2. Frequency and distribution of inefficiency explanatory variables:

(a) Frequency of northeastern Brazilian states; (b) Distribution of years of schooling;

(c) Frequency of access to credit; (d) Distribution of ratio of collective production value; (e) Distribution of access to technical assistance; and (f) Distribution of ratio of production for consumption $(n=308)$.
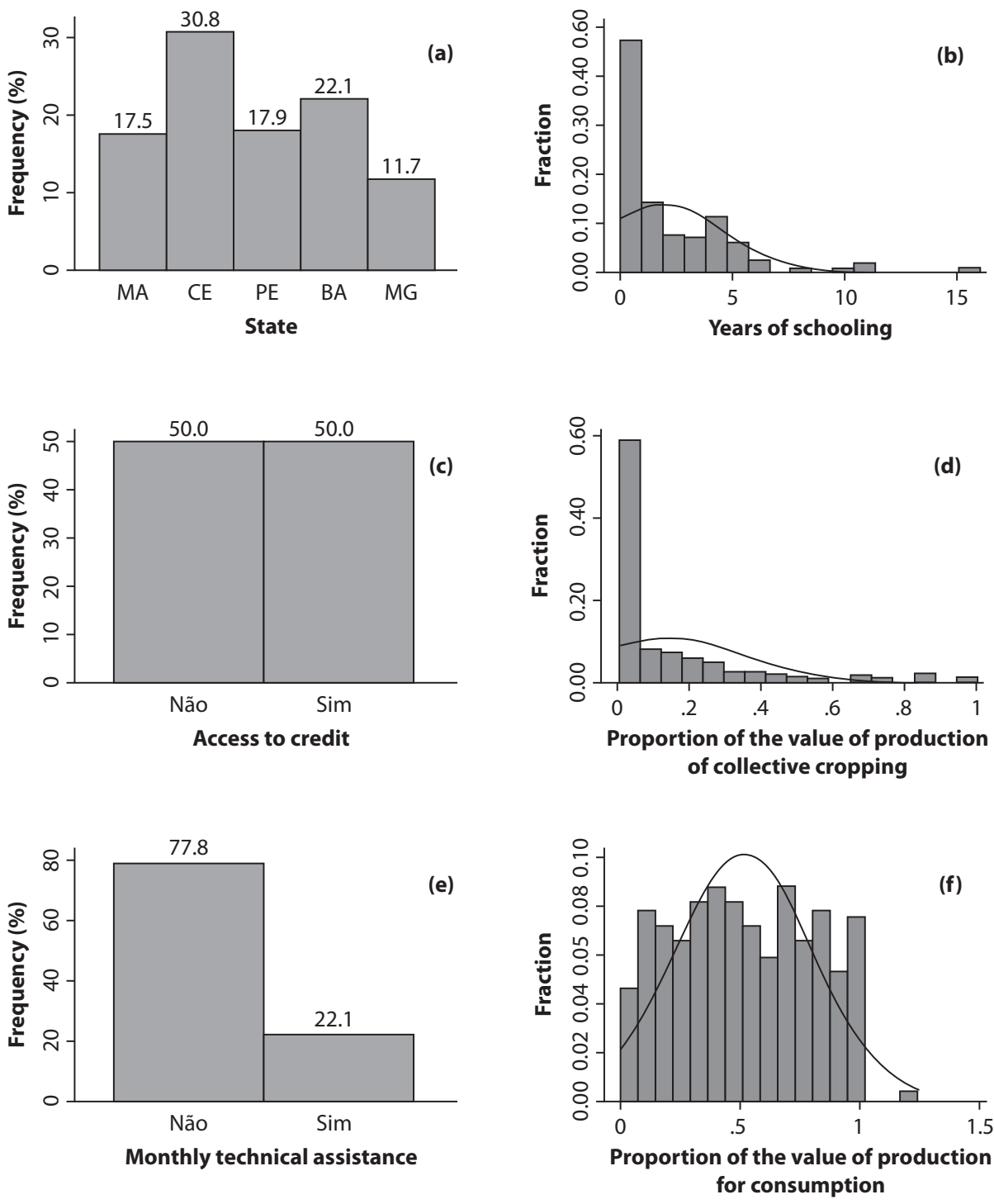

Source: Research data (2003). 
The first graph, related to the sample projects' distribution amongst the Federation units, stresses that the highest share of observations is from the Ceará state (CE) ${ }^{11}$ Most of the sample households (around 60\%) received technical assistance, which means technical guidance and support. The variable used in the frontier model was the one that represents monthly technical assistance (22.1\% of sample), with no significant results. As mentioned above, in the year $2002 / 03$, when the field research was carried out, the majority of settlements were in their first years of production. It is very important to check in future investigations if the number of people assisted by agronomists will change and if the effect of technical assistance will be relevant.

\section{Results of the SFA Model}

The results from parameters' estimations are shown on Table 2. The value found for $\gamma$ is near 1 and it is significantly different from zero, thus leading us to the conclusion that there exists a high level of technical and allocative inefficiency. Figure 3 presents the distribution of beneficiaries accordingly to their degree of technical efficiency, measured between the relation of potential and effective production $\left(T E_{i}\right)$ as depicted above. One should remark a higher concentration around the efficiency levels of $50 \%$, even though there are a higher number of producers below $50 \%$. One perceives, thus, high heterogeneity and high inefficiency.

The stochastic frontier model estimated a mean efficiency of 0.4699 and a log likelihood value of -371.5933 for the Cobb-Douglas form. The value of likelihood ratio test considering distribution $\chi^{2}(12 ; 1 \%)=26.12$ was 128.9024 (1\% significant).

The model's specification process obeyed a general to specific approach, because as it is recognized in the econometric literature, this procedure assures a higher probability of finding the "true" model. We tested several variables which we might expect a priori significant and which would reduce and explain technical and allocative inefficiency. In the choice of the effectively used variables we constructed a correlation matrix between variables in order to avoid correlation between estimators and we eliminated those variables whose correlations were higher in order to keep good statistical properties for the model.

11 Notice that MA stands for Maranhão state, CE for Ceará, PE for Pernambuco, BA for Bahia, and MG for Minas Gerais. See Annex 1 for the definition of variables. 
Table 2. Results of the stochastic frontier production model for the sample of beneficiaries of PCT, $2003(n=308)$.

\begin{tabular}{lcccc}
\hline \multicolumn{1}{c}{ Group } & Parameter & Coefficient & Standard error & t-ratio \\
\hline \multirow{2}{*}{$\begin{array}{l}\text { Production } \\
\text { function }\end{array}$} & Intercept & 6.885845 & 0.469315 & $14.6721^{3}$ \\
parameters & Log Land & 0.098966 & 0.046749 & $2.1170^{2}$ \\
& Log Labor & 0.275528 & 0.078228 & $3.5221^{3}$ \\
& Log Inputs & 0.032212 & 0.014172 & $2.2729^{2}$ \\
\hline & Intercept & 0.580535 & 0.592863 & 0.9792 \\
& MG & -1.625327 & 0.535469 & $-3.0353^{3}$ \\
Inefficiency & MA & -2.575143 & 0.654778 & $-3.9328^{3}$ \\
explanatory & CE & -2.462321 & 0.622151 & $-3.9578^{3}$ \\
variables & BA & -1.105210 & 0.389425 & $-2.8381^{3}$ \\
coefficients & Schooling & -0.048335 & 0.048537 & -0.9958 \\
& TechAssist & 0.065719 & 0.331144 & 0.1985 \\
& Credit & -0.245918 & 0.283601 & -0.8671 \\
& PCollective & 0.897408 & 0.576870 & 1.5557 \\
& PConsumption & 2.534054 & 0.671792 & $3.7721^{3}$ \\
& $\sigma^{2}$ & 1.363895 & 0.329811 & $4.1354^{3}$ \\
\hline
\end{tabular}

${ }^{1} 10 \%$ significant; ${ }^{2} 5 \%$ significant; ${ }^{3} 1 \%$ significant.

Source: Research data (2003).

Figure 3. Distribution of the estimated technical efficiency:

(a) Percent of total beneficiaries; and (b) Density function of technical efficiency. Sample of beneficiaries of Cédula da Terra Program, $2003(n=308)$.
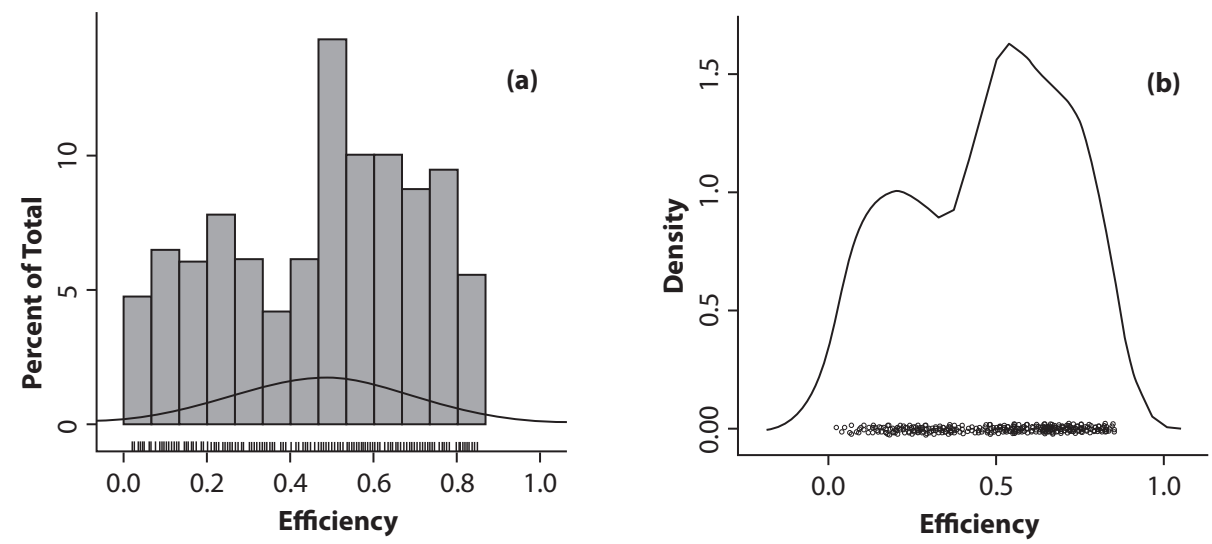

Source: Research data (2003).

In the specified and estimated model all the factors have positive signals and are significant. The factor which most determines production is essentially labor, whose estimated parameter is high and statistically significant (Table 2). 
Land and inputs, have almost no weight in the determination of the value of production, because these estimated parameters are near zero. This result is coherent for the target-public of land reform farmers, because they use labor intensive technology and a low use of external inputs.

One should take notice that the data we used for land refers to cultivated area and not available area. Accordingly to the estimated model, an increase in cultivated area wouldn't have a significant impact on the value of production output - thus leading us to conclude that there are other variables as determinants of output, namely those associated with explaining technical and allocative efficiency. Most of the beneficiaries of the PCT (Cédula Program) use still a very small fraction of the land they have available to them, and thus wouldn't have constraints to output growth using this available factor. As it shall be shown afterwards there is still a very large output growth opportunity independently of growing explored area.

The use of the inputs is still a low, or almost nil, for the PCT beneficiaries. Again, increases in output are, accordingly to the model, more related to other conditionings - independently to the use of these variable inputs. Consistent with the production function and the reduced importance of land and inputs, the variables that are traditionally responsible for reduction of technical inefficiency have shown no significant effect in the model.

Credit is also a productive factor which mitigates technical inefficiency, because it enables a better access to use resources, in a way which effectively increases the productivity in the farm, besides enabling the adoption of higher value products. In spite of the sign of the variable credit access is as expected, the statistical result is not significant, indicating the stage of the majority of settlements. After four or five year project only $50 \%$ of the sample interviewers had already taken credit.

In the model technical and allocative inefficiency decrease when the value of social production - value of output in society - increases, but it is not significant. Buainain et al. (2003) indicate that besides the percentage of collective work to be reduced, there was evidence of its reduction over time, fact that confirms Romano et al. (2008) results about the low level of social capital in PCT settlements.

The parameter of production value for self-consumption presented the higher level of (negative) effect on efficiency, with statistical significance. The positive sign of self-consumption means that an increase in the production for self-consumption. This result is coherent with the idea that this variable reveals beneficiaries in the early stages of exploitation of the resources provided by the project, identified by the model as a determinant of relative inefficiency. Further investigations on PCT should reveal a significant reduction in the importance of self-consumption and a catch up to the efficiency frontier by people who is laggard behind in the year 2003. 
There is heterogeneity, even within states, in terms of production systems. The dummies for Minas Gerais, Maranhão, Ceará and Bahia are significant, which means that all of the interviewers from these four states are in better efficiency situation in comparison to Pernambuco. Although the regionalization by state is not a good specification to establish differences amongst technical and allocative efficiency, used here as control variables, the fact that Ceará show higher efficiency fits the results of other works, like Buainain et al. (2003) and Romano et al. (2008). The model could possibly be improved by the use of proxies, which might represent areas with lesser heterogeneity or specific production systems. $^{12}$

The results in Table 2 show that technical assistance was irrelevant technical inefficiency explanatory factor. However, the positive sign confirms the idea of low degree of maturity of the PCT beneficiaries to agricultural production in the first stage of their participation in the project. So much effort was put in guarantee infrastructure, as Buainain et al. (2002) had already pointed out. Another variable tried initially was the participation in technical courses, but it also was not significant. One should notice that this latter variable has a higher demand for human capital (formation) and that in fact the schooling of these farmers is so low - thus this might explain why technical courses didn't reduce technical and allocative efficiency.

We also tried to evaluate the impacts of the different performed types of productive activity (animal vs. vegetable) thus creating a variable which was the share $(\%)$ of animal production in total production (animal + vegetable). The differences between these two types of production didn't seem relevant, as the variable was reported as non-significant.

Age is a proxy for experience (accumulated human capital) but didn't also shown as significant. In this context one must analyze the farmer's age under two different effects: i) a pro-efficiency effect - older farmers implied more experience with inputs use, irrigation techniques, seed selection and ii) antiefficiency effect - the older farmer is more risk averse and denies to try new techniques. In our analysis we didn't obtain success to know which effect came to be dominant, or even if the two effects balanced each other.

In this line of reasoning we analyzed other variables such as seed and both weren't significant. Such finding isn't striking, once we recognize that these variables are associated to a capital intensive use and as we already reported the capitalization level is too low.

We also tried in the model the use of fodder, which we might expect to reduce technical inefficiency. Again this parameter didn't show up as significant.

12 A drought in many Pernambuco regions for our sample period may explain why their settlements were in worst position regarding efficiency. Bad governance could give another explanation to it (see BUAINAIN et al., 1999b). 


\section{Final Considerations}

The result of the present study shows that the production of the beneficiaries of Cédula da Terra Program depend mainly on intense use of labor, a resource available with low opportunity cost in Northeast Region of Brazil. Land and variable inputs did not show as determinant factors of production. Various reasons or causes might explain this. As it was stressed by Buainain et al. (1999a, $1999 \mathrm{~b}, 2002)$, the beneficiaries face credit restrictions to perform the needed investments, which would qualitatively change the productive structure. The resources provided by the Cédula da Terra Program for initial installation in the settlement had an upper limit given by the operating rules of the program itself. This limit didn't guarantee minimum production growth in subsequent years. These restrictions implied a partial and fragmented adoption of a minimum required technology package, which may have had a more substantial impact on production, such as irrigation infrastructure, which was seldom implemented. On the other hand, part of productive investments which incorporate new levels of technology had not matured five years after the settlement of the families, and thus the current traditional production adopted by settlers in the region is still going on as before. In most cases, these traditional systems use low levels of technology and few external inputs, and thus the production growth responds mainly to the use of labor.

The finding of the econometric study that production does not respond to increase of the cultivated area can be explained by the features of the predominant production systems in the settlements. Those systems are based on a consortium of mixed cultures and rotation with animal breeding. The available area for exploitation is larger than the family's ability to use it, which highlights the technological limitations of the settlers for agricultural production. The role of climatic and soil conditions in many areas are not suitable for farming, which also explains the result obtained in estimating the production function. Additionally, in the semi-arid region, the use of larger areas with low productivity is combined with those areas where the production is more intensive. The latter are smaller areas, such as meadows, which tend to receive higher intensity of use.

This result cannot be used to justify the abandonment of the use of external inputs or to justify a strategy to intensify land usage. One should notice that this result reflects, a priori, a set of restrictions on the use of these factors - and does not reflect an intrinsic producer's rationality - thus, the level of factor's use is low and its impact is residual. Land is a factor which exists as a reserve, and will surely be determinant for the expansion of production, but not necessarily determinant for the growth of production value, as reported by the model.

The fact that the production function is just a function of labor, is consistent with the analysis that a more intense use of labor would lead to a theoretical 
expansion path on which the optimal rule would be marginal labor productivity matching wage. As labor marginal productivity is very low, this analysis is coherent with the existence of very low equilibrium of wages in this factor market.

However, land and capital on the current phase of the process are relatively abundant, which is an apparent paradox, while the cost of capital is higher to small farmers than to capitalists. The results presented in Table 2 do not change significantly when using the potential area (ideally available) rather than the area actually exploited by the settlers. It confirms the arguments above, regarding the low quality of the productive projects in the majority of settlements, observed by the authors in the field research.

The effect of the proportion of self-consumption on the total agricultural production on (in)efficiency is mostly an indicator of the fact that many settlements were in their beginnings when the field research was carried out. It brings out the perception that everything is happening in a very slow pace, but not justifying an idea that the beneficiaries are not working to become agricultural producers.

The analysis of technical efficiency stresses important elements to understand the constraints on production. Settlers are spending money to pay for technical assistance services with bad results, as confirmed by the negative signal of the parameter. One should remark the precariousness of the technical assistance service in most states. Probably those settlers, who had better technical assistance service, were able to reduce technical and economic inefficiency.

This is once more a confirmation, which is present and is repeated over and over again in the literature and on the political claims of the farmers, that access to land, by itself, isn't enough to have an efficient resource use and high production, because farmers do face dire external restrictions. Secondly, our analysis shows the importance of education. The very low schooling levels that characterize the beneficiaries of the Cédula da Terra Program explains part the constraints they face to produce. Education interacts with technical assistance by easing apprenticeship and the absorption of new concepts, and also contributes to a better credit access, without even mentioning better access to global markets.

The main policy conclusions are that one should increase credit and technical assistance as first line priorities for the reduction of technical inefficiency. Secondly, one should reinforce education policies with longer term results. These variables shape the ability to obtain better prices, to reach better markets, to adopt new products and techniques, which might not only raise productivity, but also raise the value of production.

Further investigations in the Cédula da Terra projects can take the results of the presented model as a reference and a foundation to study land usage, labor usage, and inputs productivity improvements. 


\section{References}

BATTESE, G. E.; COELLI T. J. (1995), "A model for technical inefficiency effects in a stochastic frontier production function for panel data", Empirical Economics, 20, 325-332.

BECKER, G. (1993), Human capital: a theoretical and empirical analysis with special reference to education, $3^{\text {rd }}$ edition, University of Chicago Press, USA. (1 $1^{\text {st }}$ edition -1964$)$

BRITANNICA (1993), "Land reform and tenure”, Macropedia Knowledge in Depth, v. $22,15^{\text {th }}$ edition, pp. 540-547.

BRITANNICA (2001), "Land reform and tenure", Britannica Edition Super Deluxe in CD Rom, Merrian Websters Collegiate, $10^{\text {th }}$ edition, US Patent \#5,241,671.

BUAINAIN, A. M.; SILVEIRA, J. M. F. J.; ARTES, R.; MAGALHÃES, M. M.; BRUNO, R. (1999a), Avaliação Preliminar do Programa Cédula da Terra. Convênio IE/Unicamp, NEAD-MDA, Banco Mundial. 321p. (mimeo)

BUAINAIN, A. M.; SILVEIRA, J. M. F. J.; SOUZA FILHO, H. M.; MAGALHÃES, M. M. (1999b), "Community-based land reform implementation in Brazil: a new way of reaching out the marginalized?", Global Development Network Bonn Seminar CD Rom, Bonn, November/1999. 106p. http://www.gdnet.org.

BUAINAIN, A. M.; SILVEIRA, J. M. F. J.; MAGALHÃES, M. M.; ARTES, R.; SOUZA FILHO, H. M.; NEDER, H. D.; LEON, F; PLATA, L. A. (2002), Perfil dos Beneficiários PCT e INCRA, 2001, Relatório de Pesquisa. Convênio FECAMP/NEADMDA. 393p. (mimeo)

BUAINAIN, A. M; FONSECA, R. B.; PEDROSA, D.; BAZIN, F; NEDER, H.; SOUZA FILHO, H. M.; SILVEIRA, J. M. F. J.; MELO, M. F.; MAGALHÃES, M. M.; VITAL, M.; ROCHA DE SOUSA, M.; BUAINAIN, V. (2003), Estudo de Avaliação de Impactos do Programa Cédula da Terra, Relatório Final. Convênio FECAMP/NEADMDA-World Bank. 213 p. (mimeo)

COELLI, T. (1996), "FRONTIER Version 4.1: A computer program for stochastic production and cost frontier estimation". Department of Econometrics, University of New England, Armidale, NSW.

COELLI, T.; RAO, D. S. P.; BATTESE, G. E. (1998), An Introduction to Efficiency and Productivity Analysis. Kluwer Academic Press. 275p. (paper back)

CGPMA. (2008), Painel de Indicadores Gerenciais, Boletim. v. 3, n. 0029. CGPMA/ Secretaria de Reordenamento Agrário/Ministério de Desenvolvimento Agrário, Brasília-DF.

EVENSON, R. (1988), "Research, Extension and U.S. Agricultural Productivity". In: CAPALBO, S.; ANTLE, J. (Eds). Agricultural Productivity. Resources for the Future. p.289-316. 
FARE, R.; GROSSKOPF, S.; LOVELL, C. A. (1994), Production Frontiers. 1st ed., Cambridge, Cambridge University Press. 296p.

KAGEYAMA, A.; HOFFMANN, R. (2000), “Determinantes da renda e condições de vida das famílias agrícolas no Brasil". Economia e Sociedade. v. 1, n. 2, Julho/ Dezembro, ANPEC, Campinas-SP.

KAWAGOE, T. (1999), "Agricultural land reform in post-war Japan: experience and issues". Working Paper 2111, May/1999. World Bank Policy Research, Washington D.C.

ROMANO, C.; NEDER, H. D.; SILVEIRA, J. M. F. J.; MAGALHÃES, M. M. (2008), "The Impact of Market-Assisted Land Reform Program in Brazil: the case of The Cédula da Terra Program". Working Draft. mimeo.

SHARIF, N. R.; DAR, A. (1996), "An empirical study of the patterns and sources of technical inefficiency in traditional HYV rice cultivation in Bangladesh". Journal of Development Studies. 32, 612-629.

SILVEIRA, J. M. F. J.; NEDER, H. D.; MAGALHÃES, M. M.; SOUZA FILHO, H. M.; MAIA, A. G.; PEREIRA, D. F. (2008), "Metodologia do estudo de avaliação de impacto do projeto Cédula da Terra". Estudos de Reordenamento Agrário № 5. 1a ed. Brasília-DF : IICA/ MDA/ PCT-Crédito Fundiário, v. 5, p.59-89. ISBN 9788560236046.

SPAROVEK, G. (2003), A Qualidade dos Assentamentos da Reforma Agrária Brasileira. USP/MDA/FAO. 204p.

STEVENSON, R. E. (1980), "Likelihood function for generalized stochastic frontier estimation". Journal of Econometrics. 13, 57-66.

WANG, J.; CRAMER J. L.; WAILES, E. J. (1996), "Production efficiency of Chinese agriculture: evidence from rural household survey data". Agricultural Economics. $15,17-28$.

WANG, H.; SCHMIDT, P. (2002), “One-step and two-step estimation of the effects of exogenous variables on technical efficiency levels". Journal of Productive Analysis. 18, 129-144. 


\section{Annex I. Variables of the Production Function.}

\begin{tabular}{|c|c|}
\hline Variable & Description \\
\hline VP & $\begin{array}{l}\text { Value of agricultural production, which includes animal, vegetal production, derivati- } \\
\text { ves and other products; individual and social production; monetary and non-monetary } \\
\text { production. Values in current "Reais" (R\$). Value of production destined to be sold ba- } \\
\text { sed on producer's declared price. Value of non-monetary production (destined to self- } \\
\text { consumption) obtained by the inputation of prices in the following order: selling prices } \\
\text { declared by the beneficiary, when part of the production is sold; average selling prices } \\
\text { declared by other beneficiaries on the same project; average selling prices declared by } \\
\text { other beneficiaries of the same municipality; the same for microregion, mesoregion, Sta- } \\
\text { te and set of the five states. }\end{array}$ \\
\hline Land & $\begin{array}{l}\text { Area of used land with permanent and temporary crops, pastures and others in hecta- } \\
\text { res (ha). }\end{array}$ \\
\hline Labor & $\begin{array}{l}\text { Working days inside and outside the parcel, but within the project, resident dwellers, } \\
\text { third parties and members of the family non-residents in the dwelling. }\end{array}$ \\
\hline Inputs & $\begin{array}{l}\text { Total spending with variable inputs such as feed, silage, palm, grain, salt, vaccines and } \\
\text { medicines, seeds, fertilizers and correctives, agro-toxic products, packages, fuels and } \\
\text { lubricants and water for irrigation. All in current "Reais" (R\$). }\end{array}$ \\
\hline MG & Dummy which equals 1 for "Minas Gerais" state project beneficiaries. \\
\hline MA & Dummy which equals 1 for "Maranhão" state project beneficiaries. \\
\hline $\mathrm{CE}$ & Dummy which equals 1 for "Ceará" state project beneficiaries. \\
\hline BA & Dummy which equals 1 for "Bahia" state project beneficiaries. \\
\hline $\mathrm{SC}$ & Level of schooling measured by years of beneficiaries'study. \\
\hline TA & $\begin{array}{l}\text { Dummy which equals } 1 \text { for beneficiaries who obtained monthly technical assistance be- } \\
\text { tween August/2002 and July/2003. }\end{array}$ \\
\hline CRE & $\begin{array}{l}\text { Dummy which equals } 1 \text { for beneficiaries who obtained at least one credit approval (ex- } \\
\text { ception for PCT) since the beginning of the Project till July } 2003 .\end{array}$ \\
\hline VPS & $\begin{array}{l}\text { Value of collective production done in the common shared lands, monetary and non- } \\
\text { monetary production, obtained in society. Value in Current "Reais" (R\$). }\end{array}$ \\
\hline ULI & ultural production destined to self-consumption, in current "Reais" (R \\
\hline
\end{tabular}

